\title{
On the Path to Become the Eighth Wonder of the World: A Philosophical Re-examination of Nigeria and Her Chronicles of Corruption
}

\author{
Ogabo Godwin Adinya ${ }^{1}$, Dokpesi Timothy Adidi ${ }^{2, *}$ \\ ${ }^{1}$ Department of Philosophy, Faculty of Arts, University of Calabar, Calabar, Nigeria \\ ${ }^{2}$ Department of Philosophy, Faculty of Arts, Benue State University, Makurdi, Nigeria
}

Copyright $\bigcirc 2019$ by authors, all rights reserved. Authors agree that this article remains permanently open access under the terms of the Creative Commons Attribution License 4.0 International License

\begin{abstract}
To state that the challenge of corruption is one of the most debilitating issues facing Nigeria today is to over flog the obvious. In Nigeria, various metaphorical allusions have been evolved as euphemisms for corrupt behavior. Such aphorisms include: "long leg", "bottom power", "chop chop", "kick back", "scratch my back", "appreciation", "sorting", etc have been in use. It is reflected in favoritisms, nepotism, tribalism, sectionalism, undue enrichment and amassing of wealth, abuse of public office, bribery, smuggling, fraud, illegal payments, money laundering, drug trafficking, falsification of documents and records, false declaration of assets, evasion, deceit, forgery, concealment, aiding and abetting of any kind to the detriment of another person, community, society or nation, etc. Each political regime comes to power promising to eliminate the practice and punish offenders only to fall into the same gully - or even a deeper one. The impetuous ascendency of corruption in Nigeria could only be likened to a movement towards becoming the eighth wonder of the world, albeit, negatively. It is against this backdrop that this research attempts to come to terms with the problem of corruption in Nigeria with a view to finding a solution to it. The study employed the qualitative research design using secondary sources, which include books, journals and the internet. The work discovered that corruption is a major clog that impedes Nigeria's development efforts. The study found out that the major factors that fuel corruption in Nigeria include inequality in distribution of wealth, the notion of political office as the primary means of gaining access to wealth, the weakness of social and governmental enforcement mechanisms, abject poverty of the majority of her citizens and the absence of a strong sense of national community among the sections of the polity. It also found out that the major factors that fuel corruption in Nigeria include inequality in distribution of wealth, the notion of political office as the primary means of gaining access to wealth, the weakness of social and governmental
\end{abstract}

enforcement mechanisms, abject poverty of the majority of her citizens and the absence of a strong sense of national community among the sections of the polity. The study is relevant as the ogre of corruption will be reduced to its barest minimum if the recommendations of the study are taken seriously. The paper surmises that given its damaging consequence, corruption in Nigeria is not a problem whose solution can be put off to another day.

Keywords Corruption, Nigeria, Poverty, Leadership Problem, Value-Reorientation

\section{Introduction}

One of the most discussed, dreaded and abhorred, yet practiced vices today, especially in the developing and underdeveloped nations, is corruption. In Nigeria for instance, this vice has gone so endemic that no sphere of the polity is spared. Scores of those who make bold to openly condemn it in public, end up practicing it in the secrecy of their closets. Even though the phenomenon of corruption has always existed, only recently has it become a front burner in international discourse. One can rightly assert that it is not peculiar to any continent, region and ethnic group. It cuts across faiths, religious denominations and political systems and affects both young and old, men and women alike. As far as corruption is concerned, what makes a difference is that the magnitude of corruption is not equal in every society. Some countries are more corrupt than others; and while some countries practice corruption covertly others practice it overtly. Even though the majority recognizes corruption as an issue of negative concern and the bane of many societies, yet it is paradoxically the most practiced vice today. In Nigeria, for instance, corruption is found in high and low places; it 
manifests itself in several nefarious activities: misappropriation of budgeted funds, disappearance or slow movement of files in offices, police extortion at the numerous checkpoints, queues at filling stations occasioned by hoarding, ghost workers syndrome, election irregularities and cut-backs in banks to evade due process, among others. Those who often mount the roof top to condemn corruption also practice it in the secrecy of their closets. Many of our preachers who condemn it are equally too eager to share in its proceeds whenever an opportunity offers itself. This is why most scholars have concluded that corruption is the bane of Nigeria. This paper, therefore, seeks to $x$-ray the menace of corruption in Nigeria, identify its effects as well as proffer possible solutions towards curbing corruption in Nigeria. It is worthwhile to proceed by explaining adequately what corruption actually means.

\section{Conceptualizing Corruption}

Corruption is one of those concepts that have defied a univocal definition over time. This does not mean that it is devoid of a definition. Instead, it has been accorded various definitions, usually depending on its style, magnitude and the defining field of study. The Webster's new encyclopedic dictionary [1] associates corruption with 'moral debasement and depravity; inducement to do wrong by unlawful or improper means as briber, and departure from what is pure or correct' (p.226). Sen [2] conceptualizes that "specifically, corruption or corrupt behaviour involves the violation of established rules for personal gain and profit” (p.275). Lipset and Lenz [3] however define corruption as efforts to secure wealth or power through illegal means, for the purpose of private gain at public expense; or a misuse of public power for private benefit (p.112-114). Gleaning from the above, one could suffice it to say that corruption is a behavior which deviates from the formal duties of a public role, because of private gains. These gains could include personal, close family, private clique, pecuniary or status gains. By these definitions, the corruption lexicon would include such things as: bribery (use of a reward to pervert the judgment of a person in a position of trust); nepotism (bestowal of patronage by reason of ascriptive relationship rather than merit); and misappropriation (illegal appropriation of public resources for private uses). [4]

\section{The Reality of Corruption in Nigeria}

Anozie [5] observes that Nigeria has been regarded by some scholars as "the home or abode of corruption" (p.145). The corruption in Nigeria could be said to have begun from the era of colonialism, but after independence, the level of corruption was heightened and became popularized. The attempt in this section is to pinpoint some large scale corrupt practices which have entrenched the ogre in the body polity of Nigeria. Most scholars seem to trace the origin of wide scale corruption in Nigeria back to the time of Obasanjo's military regime. In 1976 when General Obasanjo was the military Head of State, and General M. Buhari was the oil minister, the sum of 2.8 Billion Naira was missing from the oil account. A panel was set to investigate the scandal. As is usual in Nigeria, nothing was again heard about the investigation. When Lady Vera Ifudu of NTA Lagos dared to play the cassette of the proceedings of the panel, she was pathetically and summarily dismissed from office [5] (p.145).

During the Babangida's regime, he and few cohorts thoroughly fleeced the country of its oil bonanza. General Babangida veered from the normal federation account to surreptitiously establish the dedicated and special accounts to warehouse the crude oil proceeds. In six years (1988 1994) 12.4 billion Dollars had been recorded in the accounts. 12.2 billion was liquidated within the same period on services that are neither regenerative nor of genuine high priority. [6]

The Olabode George scam was another milestone in corruption. The report of the committee which probed the board of Nigerian Ports Authority under Chief Olabode George was a damning revelation of high fraud. The News magazine reports that within three years that George led the authority, he awarded over 29,586 contracts valued at about $\mathrm{N} 85$ billion. It was the opinion of the committee that all the contracts could be compacted into not more than 300 . To worsen the issue, the prices of most of the contracts were grossly inflated (p.22). Bode George went home securely with his loot because of his relationship with former President Olusegun Obasanjo.

Tafa Balogun's loot was another episode that made a headline. The $\mathrm{N} 9$ billion scam was reported by the Newswatch magazine. The Lt and $\mathrm{T}$ funds which were meant for the settling of junior officers and quarter masters of the Nigerian Police Force; take care of the refurbishment of police barracks; buying of shoes and shirts for members of the police, started disappearing piecemeal until it finally vanished (p.15). Tafa Balogun was tried, convicted, but imprisoned for paltry six months. It has equally been acclaimed that General Abacha's regime is the most corrupt since Nigeria's history and Abacha himself the most corrupt president since the history of Nigeria. He stole and banked Nigeria's money in over 130 banks overseas (Anozie 147). [5] More recently, in the Jonathan's administration, the teeth of organs of government that hitherto prevented corrupt practices like EFCC, ICPC, NDLEA have been plucked off, leaving them only "toothless bull dogs". The squandermania of the likes of Oduah and Madueke are still fresh in the minds of Nigerians.

The degree at which corruption in high and low places proliferated and became entrenched in political and 
corporate life in Nigeria is alarming. Paschal Dozie decried the situation in the Daily Times thus, "corruption...has almost destroyed all aspects of our national life - be it our social life, intellectual development, educational system, creativity, value system, interpersonal relationship and external image both as individuals and as a nation" (qtd. in Uzoukwu 265).[7] In their own words, the Catholic Bishops of Nigeria observed that corruption has become "so pervasive that many now accept it as the Nigerian way of life or Nigerian way of doing things." (p.266). [7] No wonder, Transparency International, a non-governmental organization, had in 1996 and 97 rated Nigeria topmost on the list of most corrupt countries of the world.

Today, corruption has ensconced itself in every nook and cranny of the Nation's life. In the political arena, there is a marked squandermania and embezzlement of funds earmarked for public projects; there is a gross over-pricing of contracts which are hardly executed; there is demand for kickbacks and bribes before doing a job that one is paid for.

In the educational sector, the story is even becoming pathetic. Ogabo [8] reported that JAMB, WASCE, GCE and NECO "live examination papers" are circulated weeks or days before the actual exams, and certain centres reputed to be "magic" centres attract the highest population of students, especially during registration for these external examinations. In the Universities, some lecturers demand for money from male students and either money or sexual gratification (or both) from female undergraduates for academic favours.

In police checkpoints and stations, the situation is appalling. Today, a handshake with any police man is literally translated, or suspected to be a bribe. Police check points are increasing, the amount charged at such illegal "toll gates" are varying; the number of accidental discharges due to non-conformity to these toll fees are in the increase; the police frequently cash in on the public's ignorance to ask for cash in order to bail an innocent suspect. Some have even been accused of assisting criminals in the discharge of their nefarious activities. Yes, corruption has become synonymous with Nigeria, true to Achebe's [9] observation that "keeping an average Nigerian from being corrupt is like keeping a goat from eating yam" (p.26). People have now normalized and exchange bribes so freely without the inner voice of conscience, a fatal stage of corruption. To buttress the above assertions, the 1996 Study of Corruption by Transparency International and Goettingen University ranked Nigeria as the most corrupt nation, among 54 nations listed in the study, with Pakistan as the second highest (Mauro p.4). [10] As if this was not too bad enough, the 1998 Transparency International Corruption Perception Index (CPI) of 85 countries, Nigeria was 81 out of the 85 countries pooled. And in the 2001 Corruption Perception Index (CPI), the image of Nigeria slipped further down south (ranked 90, out of 91 countries pooled), with second position as most corrupt nation, with
Bangladesh coming first. [11]

\section{Forms of Corruption in Nigeria}

In Nigeria today, one could make a never-ending list of various forms of corrupt practices. Anozie[5] itemizes the commonest practices that could be included in the lexicon of corruption to include: graft, fraud, embezzlement, looting of public till; misuse of public funds, stealing of government property; over-invoicing of goods and services; inflation of government's contracts, payment for contract not executed; illegal acquisition of public property; false declaration of assets and falsification of accounts; collusion with transnational companies to evade tax; diversion of public funds to privates uses or accounts; importation of fake products and payment of ghost workers; asking and receiving bribes in the name of kickbacks; favouritism and deprivation of people's rights; appointments not based on merits; examination malpractice; settlement, sorting out, admission racket, award of marks not based on merit; sucking the gullibility of ignorant congregation with promises of miracles that are directly proportional to the size of one's tithes, all in the name of God (p.138).

The classification given by Dike [10] is equally insightful and embracing. He divides corruption into three major forms, viz:

i. Political Corruption: This takes place at the highest levels of political authority. It occurs when the politicians and political decision-makers, who are entitled to formulate, establish and implement the laws in the name of the people, are themselves corrupt. It also takes place when policy formulation and legislation is tailored to benefit politicians and legislators.

ii. Bureaucratic Corruption: This form of corruption occurs in the public administration or the implementation of political decisions. It is the kind of corruption citizens encounter daily at places like the hospitals, schools, local licensing offices, police, taxing offices, etc.

iii. Electoral Corruption: This includes purchase of votes with money, promises of office or special favors, coercion, intimidation, and interference with freedom of election. Corruption in office involves sales of legislative votes, administrative, or judicial decision, or governmental appointment.

Having identified the forms of corruption in Nigeria, it is pertinent here to present a record of some corrupt regimes in Nigeria.

\section{Possible Causes of Corruption in Nigeria}

Various factors have been identified by scholars ranging 
from political, cultural, religious, ethno-linguistic, among others, as causative to the widespread corruption in Nigeria. It is apt to thematically present these factors here.

i. Societal Ethical Depravity: One of the reasons for the endemic corruption in Nigeria today is what might be termed ethical misconception. Morality has so waned today in the Nigerian society that right seems to be seen as wrong and vice versa. No Nigerian official would be ashamed or condemned by his people upon the accusation of being corrupt. On the contrary, the officer would be hailed as being smart, considered as a successful man. Infact, any government official or politician who is in position but fails to enrich himself fraudulently will be ostracized by his people upon leaving office. Thus, when an average Nigerian assumes any high office, he thinks first of making a ransom so as to be regarded as successful when he leaves office. The lack of ethical standards throughout the agencies of government and business organizations in Nigeria is a serious drawback. According to Bowman [12], ethics is action, the way we practice our values; it is a guidance system to be used in making decisions. The issue of ethics in public sector (and in private life) encompasses a broad range, including a stress on obedience to authority, on the necessity of logic in moral reasoning, and on the necessity of putting moral judgement into practice (p.19). Unfortunately, many officeholders in Nigeria (appointed or elected) do not have clear conceptions of the ethical demands of their position. Even as corrupt practices are going off the roof, little attention, if any, is being given to this ideal.

ii. Collapse of traditional institution: The traditional institution has waned almost to a level of moral collapse. Traditional rulers today are ready and willing to bestow chieftaincy titles on their subjects who have looted public treasury. Chieftaincy titles are no longer given as a result of meritorious service and honour, but depending on who can pay for such titles. This tide has even affected the religious institution as some of these moneybags apart from purchasing stupendous traditional titles, even purchase church titles and knighthood honours. Thus, many people want to be rich enough to purchases these titles and so sweep the treasuries dry whenever they are given the least opportunity to serve their father land in any capacity.

iii. Poor Reward System: Onalaja and Onalaja [13] aver that Nigeria's reward system is, perhaps, the poorest in the world. Nigeria is a society where national priorities are turned upside down; hard work is not rewarded, rather rogues are often glorified. The trouble with Nigeria is not that our capabilities are inadequate. Instead, it is that our priorities - which mean our values, are wrong. And peer community and extended family pressures, and in most cases polygamous households act to worsen the situation (p.122). The extended family system in Africa generally, with the desire to satisfy members of the family, forces most office holders to loot public purses in order to meet this demand, thus leading to corrupt practices.

iv. Ineffective taxing system: Nigeria is like the proverbial "Banana Republic" where anything can happen in terms of taxation. People are taxed without adequate assessment of their incomes and sources of such incomes. This makes some people to be over taxed and others under-taxed. This system, which makes it difficult to track down people's financial activities, breeds corruption. Many unscrupulous officials of the various tax agencies cash in on this situation and extort monies from innocent citizens, or accept bribes from some highly placed individuals to aid them evade proper taxation. Ineffective taxing system is a serious problem that rears corruption in Nigeria (p.123). [13]

v. Poor Enforcement of Legislations: Most scholars have averred that Nigeria has beautiful enactments in her constitution, but the problem is that of enforcement. The unscrupulous attitude of those who are supposed to enforce the laws of the land (judges, police officers and public officials) could lead to people engaging in corrupt behavior, knowing full well that they would get away with it, sometimes even aided by the enforcement officers. Thus, police officers have often been accused of assisting armed robbers in their operations; while judges have been accused of thwarting the truth tin favour of who can pay for justice. This is a practical fuel to corruption.

vi. Lack of Economic Opportunities: The type of leadership we have witnessed in Nigeria over the past years are not such that have created the relevant economic structures to accord people opportunity to have the wherewithal to invest. Lipset and Lenze [3] note here that those going through corrupt means, to achieve their objectives have little or no access to opportunity structure. They opine that the hindrance to economic opportunity could be a result of their race, ethnicity, lack of skills, capital, material and other human resources. And the truth is that cultures that stress economic success as an important goal but nevertheless strongly restrict access to opportunities will have higher levels of corruption (p.112-117). This probably explains the high incidence of corrupt behaviours in Nigeria. Many Nigerians are highly achievement oriented, but they have relatively low access to economic opportunities. For example many teachers work for months without getting paid. Yet, the society expects them to be honest and productive. Many of those teachers working without pay are parents, who are expected to train their children in schools with empty wallets. Under this condition, 
many citizens would reject the rule of the game (societal norms) and criminally innovate to make ends meet.

vii. Quest for Flamboyant Lifestyle: It has been discovered that one of the popular, but unfortunate indices of good life in Nigeria, is flamboyant affluence and conspicuous consumption. Because of this, some people get into dubious and corrupt activities, including committing ritual murder for money-making in the bid to satisfy this quest for flamboyancy. This obsession with materialism, compulsion for a shortcut to affluence, glorification and approbation of ill-gotten wealth by the general public, are among the reasons for the persistence of corruption in Nigeria (Ndiulor p.17).[14]

viii. Irresponsible Leadership: In his polemical work, the trouble with Nigeria, Achebe [8] states unequivocally, "the trouble with Nigeria is simply and squarely a failure of leadership". For him, this problem consists in the unwillingness or inability of its leaders to rise to the responsibility, to the challenge of personal example which is the hallmarks of true leadership (p.1). We have leaders today who prepare ahead to be corrupt even before assuming office. Thus, in the words of Uzoukwu [7], "political criminalization, institutionalized robbery, mismanagement, looting, wanton insensitivity, embezzlement of funds and violations of every sort are characteristic of the Nigerian society today" (p.265).

\section{Consequences of Corruption in Nigeria}

The effects of corruption are difficult to establish with precision. However, what is clear is that the consequences of corruption are grave. Firstly, corruption is the greatest contributor to socio-economic crimes. When critically considered, corruption is the root of social crimes like drug trafficking, money laundering, illegal trade of arms and other forms of criminality. 'It reduced public spending on important sectors like education, health and agriculture' (Mauro p.199). [9] By this, it hinders the promotion of the human person, makes societies less just and threatens the security of the society.

Secondly, corruption has adverse effect on education. This stems from the fact that the corrupt government spends relatively more on items to make room for graft. And corrupt government officials would shift government expenditures to areas in which they can collect bribes easily. Large and hard-to-manage projects, such as airports or highways, make fraud easy. In addition, poverty and income inequalities are tied to corruption (Lipset and Lenz 210). [3]

Furthermore, corruption is also destructive of governmental structures and capacity. Corruption radically distorts the role of representative institutions, because they are used as an arena for political battering between clients' requests and governmental services. In this way, political choices favour the narrow objectives of those who possess the means to influence these choices and are obstacle to bringing about the common good of all citizens.

In addition, corruption is the major cause of poverty and underdevelopment. It exploits the human person and disdainfully uses men and women for self-interests. Since it is based on individual aggrandizement, it is a practical obstacle to achieving the common goal. It acts against the preferential option for the poor as it hinders the proper delivery to them of the resources intended for them. It stands in direct contrast to the universal destination of goods intended for every man and woman of the society.

It downplays the importance of honesty. Instead, corruption teaches the dangerous and wrong lesson that it does not pay to be honest, hardworking and law-abiding. This is because through corrupt means, many political office holders acquire wealth and properties in and outside Nigeria; and many display their wealth to applaud of the society. This has made politics a big business in Nigeria, because anything spent to secure a political office is regarded as an investment, which matures immediately one gets into office.

Corruption wastes skills and resources, as precious time is often wasted to set up unending committees to fight corruption, and to monitor public projects. It also leads to aid forgone. Some foreign donors do not give aid to corrupt nations. For instance, the International Monetary Fund (IMF) has withdrawn development support from some nations that are notoriously corrupt. And the World Bank has introduced tougher anti-corruption standards into its lending policies to corrupt countries.

On another note, corruption is politically destabilizing, as it leads to social revolution and military takeovers. Most "post-coup rationalizations" in less developed worlds point to corruption. Welch [15] reported that 'the General Buhari's post-coup broadcast to Nigerians in 1983 is a case in point' (p.109). It causes a reduction in quality of goods and services available to the public, as some companies could cut corners to increase profit margins. Corruption affects investment, economic growth, and government expenditure choices; it also reduces private investment (Mauro p.197). [9]

Corruption upsets ethnic balance, and exacerbates problems of national integration in developing countries. For instance, if a corrupt but popular ethnic leader is replaced in his or her position, it may upset ethnic arithmetic and the cohorts may revolt. The social brawl that followed the Moshood Abiola's 1993 elections rebuff is one of the many cases dotting Nigeria's political landscape. Southerners (mainly Yorubas from his ethnic Southwest) rioted, as they felt they were mistreated by the northern oligarchy. Similarly, "some politicians from the northern part of the country seem to have forgotten the atrocities 
committed by Generals Buhari, Babangida, and Abubakar during their regime (they even refused to testify before the Oputa Panel), because they are their home boys". [10] Any attempt to bring them to justice would lead their cronies to ethnic and social conflicts and possible loss of innocent lives.

Even though the arguments against corruption seem to be overwhelming, and despite the obnoxious and pernicious effects of corruption as seen above, some scholars have argued that corruption can be beneficial in some respects. First of all, they argue that it is beneficial to political development or "political modernization" (P.19). Political modernization or development means growth in the capacity of a society's governmental structures and processes to maintain their legitimacy over time (presumably in time of social change) by contributing to economic development, national integration and administrative capacity, and so on.

In addition, some writers have noted that corruption may help to ease the transition from traditional life to a modern political life. Some have argued that the vast gap between literate official and illiterate peasant, which is often characteristic of the countryside, may be bridged if the peasant approaches the official bearing traditional gifts or their (corrupt) money equivalent. In this respect, Ogabo [1] points out that "a degree of low-level corruption" can 'soften relations of officials and people' (p.61). He further notes that corruption can 'humanize government and make it less awesome' (p.96). These observations are common occurrences in Nigeria where communities pay political visits to their Governors, Commissioners and top civil servants with cows, wines, cola nuts and money stuffed in Ghana must go (bags) in order to get them attend to their local problems.

\section{Towards Curbing Corruption in Nigeria}

Considering the reality and endemic nature of corruption in Nigeria as seen in the foregoing, one might ask, will it be possible for Nigeria to effectively tame the scourge of corruption in the society? To answer this question, one must warn that no single and simple remedies are available for curbing corruption in Nigeria; and the problem cannot be solved overnight, because, as we have noted, corruption has been ingrained into the fabric of the society. In the light of the above assertion, the following recommendations are therefore made towards curbing corruption in Nigeria:

\section{i. Proper Execution of Anti-corruption Policies}

Osoba [17] maintains that 'many scholars are of the view that one of the reasons why the measures against corruption have not been fruitful in Nigeria is that they have operated at a level of mere symbolism without concomitant praxis'
(p.96).This is true because, those waging the corruption-wars are themselves corrupt. That is why all efforts and codenames that have been aimed at fighting corruption have instead witnessed it blossoming the more. There is thus urgent need for a proper execution of the already formulated anti-corruption policies. Agencies for the execution of these policies should be handled by scrupulous people who would carry out their duties in honesty and spirit of service to their fatherland.

\section{ii. Value Re-orientation}

Nigeria, nay any nation, cannot effectively control the menace of corruption by merely instituting probe panels or setting up agencies. Instead, the general population should be re-orientated to a better value system. This is because Nigerians have for long been living on the survival of the fittest and grab-whatever-comes-your-way mentality. The re-orientation of the youth in Nigeria to a good value system could help in the war against corruption. One way to do this is by preaching the gospel and practice of virtue towards general behavioural change, which could lead to reduction in corruption.

\section{iii. Adherence to the Rule of Law}

Nigeria is a country that celebrates the Sacred Cow syndrome. Justice means justice for the rich. Experience has shown that while the Justice Oputa Panel and the Justice Akambi commission and other related panels cruise the cities interrogating the poor corrupt individuals involved in petty thefts, the politicians and the known corrupt ex-military Generals are busy politicking around the nation with money stuffed in their Ghana-must-go bags unperturbed. The truth is that, to win the apparent war on corruption in Nigeria, the Obasanjo's slogan of there must be no sacred cows, should not be a mere political rhetoric. It should be put into practice by prosecuting all the known corrupt political heavy weights in the society, as they contribute in making the nations inchoate laws inoperable. As Agabi [18] opines, 'except you go after the big criminals and bring them to book, the rate of crime may not reduce. If you bring three or four of these big men to book, the rate of criminal activities would reduce. Arrest ministers, arrest the big people and others would fear' (p.21), and this would go a long way in curbing corruption.

\section{iv. Upholding Ethical Standards}

To win the war on corruption, adherence to ethical standards in decision-making must be the foundation of the nation's policies. Without ethics in the conduct of the affairs of the nation, the apparent wars on corruption in Nigeria will not be successful. In other words, without ethics, any money budgeted toward fighting corruption in Nigeria is a thing cast to the wild cat. Nigeria has to make 
laws and implement them to the latter. As Ogabo [15] reechoes the words of Aristotle, the aim of ethical philosophy is practical - to make us better men (p. 280). The nation has to make sure that those entrusted to execute the war on corruption are men and women of virtue - those who recognize and always do what is right. It is only when armed with ethics and virtue that the nation can then set out to reduce personal gains to corrupt behavior with tough penalties on the culprits.

\section{v. Strengthening the Media}

The mass media has a crucial role to play in the campaign to educate the people of their rights as citizens, and in exposing the rogues. Nothing chills nonsense more than exposure to thin air. For effective control of corruption in Nigeria, the society must develop a culture of relative openness, in contrast to the current bureaucratic climate of secrecy. The nation should erect permanent structures in the society to constantly tackle corruption, instead of setting up ad-hoc corruption-panels here and there. Governmental affairs should be publicized in order to allow the public follow the tide and contribute their quota to the progress of the state. The nation should also mobilize for adequate circulation of the programme of value-reorientation through the social media so that individuals and groups could learn from such programmes and become enlightened and ethical.

\section{vi. Creating an Objective Merit System}

Pye [18] is of the opinion that an objective merit system should be enabled instead of the tribal bias, state of origin and nepotism or favoritism, which has colored the nation's landscape, especially in employment and distribution of national resources, etc. Equally, the remuneration of workers should be considered top priority in government list. Wages should be adequately reviewed and paid as at when due so that workers can cater for the needs of their dependents rather than resort to other corrupt practices towards raising funds for survival. In addition to this, the society should institute appropriate and effective taxing system where everyone is made to explain his or her sources of income, through end-of-the-year income tax filing.

\section{Conclusions}

When Dr. Mudiaga Odje made the assertion that "In Nigeria, corruption is a science, duly practiced and perfected in laboratories before being unleashed on the nation... To the extent, in special situations, a public official may even issue an official receipt acknowledging that he has received a bribe from you. Nigeria is in fact the eighth wonder of the world", he was only over-flogging the obvious. As averred earlier, the legacy of both the military and civilian administrations in Nigeria has been a legion of looting of the nation's resources and shameless flaunting of the loot by leaders, their cohorts and stooges. Corruption has been entrenched, incensed and glorified in both high and low places. Some well-meaning scholars are of the opinion today that an average Nigerian cannot be prevented from being corrupt. And from the consequences of corruption as we have seen, corruption diverts scarce public resources into private pockets, literally undermines effective governance, endangers democracy and erodes the social and moral fabric of nations, inter alia. Even though some have argued for the benefits of corruption, the things they consider are only illusory. Any right thinking person in Nigeria where ubiquitous corruption has ravaged the society will find it impossible to agree that corruption is beneficial, no matter how plausible the arguments put forward may be. That is why it has become pertinent today to make a clarion call to all and sundry to put hands on deck towards clearing these Augean stables.

\section{REFERENCES}

[1] Webster's new encyclopedic dictionary. BD and L; 1993.

[2] Sen, A. Development as freedom. Anchor Books; 1999.

[3] Lipset, SM and Lenz, GS. Corruption, Culture, and Markets. Culture matters. Eds. LE. Harrison and H. Samuel. Basic Books; June 2000.

[4] Banfield, E. The moral basis of a backward society. Free Press; 1958.

[5] Anozie, MO. Corruption, church and society: Nigeria situation. The church and development. Eds. Madueke, J., Ezeokana, J. and Obiefuna, B. Rex Charles and Patrick Ltd.; 2008.

[6] The Okadigbo report found at last: what it says of IBB. The News, 23rd May, 2005. P.29-30.

[7] Uzoukwu, SK. Peace through dialogue and solidarity: the basis of true humanism. Snaap Press; 2004.

[8] Ogabo, GA. The pains of Nigerian Education. Iwoh and Sons; 2014. Achebe, C. The trouble with Nigeria. Fourth Dimension Publishers; 1983.

[9] Mauro, P. The effects of corruption on growth, Investment, and government expenditure: a cross-country analysis. Corruption and the global economy. Ed. Kimberly, AE. Institute for International Economics; 1997.

[10] Dike, VE. The philosophy of transforming Nigeria into a corruption-free society: are the probes the Solution? (Internet) Cited 2018 August 22. Available from http://Nigeriaworld.com/feature/ article/corruption.html.

[11] Bowman, JS. Ethical frontier in public management: seeking new strategies for resolving ethical dilemmas. Jossey Base; 1991. 
[12] Onalaja, T. and Onalaja, K. How polygamy wrecks Nigeria. CAPWONA Books; 1997.

[13] Ndiulor, NK. Building a Nigeria of our dreams. Bookbuilders; 2007.

[14] Welch, C. The military and the states in Africa: problems of political transition. Ed. Zaki, E. The African states in transition. St. Martins Press; 1987.

[15] Ogabo, G.A. Path to true peace and happiness. Iwoh and sons; 2008.

[16] Osoba, LN. When corruption prevails. Onibonoje press; 2012.

[17] Agabi, G. How to curb corruption in Nigeria. The Vanguard, $30^{\text {th }}$ March 2002.

[18] Pye, L. The concept of political development. The Annals. 1965 March 35(8): .11-19. 